\title{
Thiophanate-Methyl Resistance and Fitness Components of Colletotrichum musae Isolates from Banana in Brazil
}

Willie Anderson dos Santos Vieira, Waléria Guerreiro Lima, Eduardo Souza Nascimento, Sami Jorge Michereff, and Ailton Reis, Departamento de Agronomia, Universidade Federal Rural de Pernambuco, Recife, 52171-900, Pernambuco, Brazil; Vinson P. Doyle, Department of Plant Pathology and Crop Physiology, Louisiana State University AgCenter, Baton Rouge, LA 70803; and Marcos Paz Saraiva Câmara, Departamento de Agronomia, Universidade Federal Rural de Pernambuco, Recife, 52171-900, Pernambuco, Brazil

\begin{abstract}
Anthracnose, caused by Colletotrichum musae, is the most important postharvest disease of banana and is widely distributed among the banana production regions in Brazil. Although thiophanate-methyl is a fungicide frequently used in Brazilian banana orchards to control Sigatoka leaf spot, Collettotrichum populations are also exposed, resulting in the evolution of fungicide resistance and the inability to manage banana anthracnose. We investigated 139 Brazilian isolates of $C$. musae for thiophanate-methyl sensitivity in vitro. The $50 \%$ mycelial growth inhibition $\left(\mathrm{EC}_{50}\right)$ values varied between 0.003 and $48.73 \mu \mathrm{g} / \mathrm{ml}$. One-hundred and thirty isolates were classified as sensitive, with $\mathrm{EC}_{50}$ values ranging from 0.003 to $4.84 \mu \mathrm{g} / \mathrm{ml}$, while the remaining nine isolates were considered moderately resistant, with $\mathrm{EC}_{50}$ values ranging between 10.43 and $48.73 \mu \mathrm{g} / \mathrm{ml}$. Resistant or highly resistant

isolates $\left(\mathrm{EC}_{50}>100 \mu \mathrm{g} / \mathrm{ml}\right)$ were not found. A substitution of TAC for TTC at codon 200 in a coding region of the $\beta$-tubulin gene was associated with the moderately resistant phenotype. Applications of thiophanate-methyl formulation to detached banana fruit at the label rate $(500 \mu \mathrm{g} / \mathrm{ml})$ showed low efficacy in controlling the moderately resistant isolates on banana fruits. However, there is no indication of a reduction in fitness associated with fungicide resistance as sensitive and moderately resistant isolates do not differ with respect to mycelial growth rate $(P=0.098)$, spore production $(P=0.066)$, spore germination $(P=0.366)$, osmotic sensitivity $(P=0.051)$, and virulence $(P=0.057)$. Our results revealed absence of adaptability cost for the moderately resistant isolates, suggesting that they can be dominant in population if the fungicide continue to be applied.
\end{abstract}

Brazil is the fifth-largest producer of banana (Musa spp. L.) worldwide, surpassed only by India, China, the Philippines, and Ecuador. Annual banana production in Brazil constituted about $6.8 \%$ of overall global production in 2014, represented by $7 \mathrm{M}$ tons of fruit from a harvested area of 478,765 ha (FAO 2014). Fruit quality can be impacted by diseases caused by postharvest pathogens such as Lasiodiplodia and Colletotrichum (Sepiah et al. 1990). These pathogens can limit the exportability of Brazilian fruit, preventing long-distance transport, as well as preventing entry to its final destination (Peres 1998; Prusky and Plumbley 1992). Anthracnose caused by Colletotrichum musae is the most important postharvest disease of banana and it is present in all production areas worldwide. Although the disease can occur at any time during the growing season, it is most frequent on ripe banana fruit (Simmonds and Mitchell 1940). The pathogen starts as a quiescent infection on green fruit, while symptoms generally develop in overripe fruits or fruits ripened at high temperatures (Lim et al. 2002; Meredith 1960).

Anthracnose management is aimed at preventing infection and delaying symptom development by reducing inoculum at its source (Zambolim et al. 2002). This includes frequent defoliation of banana and removal of crop debris. It is also necessary to prevent injuries to the fruit during harvest to minimize anthracnose development (Cordeiro 1997). Fruit treatment with fungicides, especially with benzimidazoles, is commonly used for postharvest control of anthracnose (Eckert and Ogawa 1985), which limits exposure of isolates in the field and prevents the emergence of fungicide resistance.

While thiabendazole is the only fungicide of the methyl benzimidazole carbamate (MBC) group registered for postharvest treatment of banana in Brazil (MAPA 2016), another MBC group fungicide, thiophanate-methyl, is commonly applied to banana orchards in Brazil. Thiophanate-methyl is registered for the chemical control of yellow Sigatoka leaf spot caused by Mycosphaerella

Corresponding author: M. P. S. Câmara, E-mail: marcos.camara@ufrpe.br

Accepted for publication 15 May 2017.

C 2017 The American Phytopathological Society musicola (MAPA 2016). Although thiophanate-methyl is not used in the field for controlling anthracnose, C. musae populations are exposed to the fungicide. This incidental exposure of populations of C. musae to thiophanate-methyl in Brazilian banana orchards provides the selective pressure for thiophanate-methyl and other MBC fungicide resistance to evolve.

A reduction in fungicide sensitivity is among the most important factors reducing the success of chemical control of plant diseases. This reduction in sensitivity has been commonly observed after the introduction of fungicides with a single mode of action (Avenot and Michailides 2010; Brent and Hollomon 2007a, b; Kuck et al. 2012; Ma and Michailides 2005). MBCs bind to $\beta$-tubulin subunits and inhibit nuclear division (Davidse 1986). Non-synonymous (amino-acid modifying) point mutations in the $\beta$-tubulin (TUB2) gene are known to be responsible for the development of resistance to $\mathrm{MBC}$ fungicides in several fungal species, such as Colletotrichum spp., Monilinia fructicola, Cochliobolus heterostrophus, Penicillium spp., Botrytis cinerea, Helmintosporium solani, Sclerotinia sclerotiorum, and Venturia spp. (Chung et al. 2010; Ma and Michailides 2005).

Although amino acid changes at one of many positions (codon 6, 50, 167, 198, 200, and 240) (Ma and Michailides 2005) can lead to MBC resistance, mutations at codon position 198 (glutamic acid to alanine - E198A, to glutamine - E198Q, or to lysine - E198K) and 200 (phenylalanine to tyrosine - F200Y) are the most commonly reported for the genus Colletotrichum. A mutation at codon position 198 is mostly found in isolates with high levels of resistance, while a mutation at position 200 is correlated with moderate resistance (Chung et al. 2006, 2010). The E198A amino acid change has been reported in resistant Colletotrichum isolates from Citrus in Brazil and the United States (Peres et al. 2004), Limonium spp. in Israel (Maymon et al. 2006), turf grass and creeping bent grass in the United States (Wong et al. 2008), several fruit crops in Japan (Chung et al. 2010), mango in Thailand (Kongtragoul et al. 2011), peach and blueberry in the United States (Hu et al. 2015), and bell pepper in Trinidad (Ramdial et al. 2016). Correlations between moderate resistance to $\mathrm{MBC}$ and the $\mathrm{F} 200 \mathrm{Y}$ amino acid substitution has been found with Colletotrichum isolates from bell pepper in Trinidad (Ramdial et al. 2016), and strawberry and grape in China (Lin et al. 2016). 
Fungicide resistance can be defined as a stable and heritable adjustment by a fungus to a fungicide, resulting in sensitivity reduction of the fungus to specific fungicide dosages that previously provided effective control. However, resistance may have a fitness cost (Ma and Michailides 2005). Fitness can be defined as the ability of a fungal isolate to develop, reproduce, survive, and cause disease. Mycelial growth, reproductive potential, and virulence are some examples of fitness components evaluated in populations of plant pathogens to determine the cost associated with resistance (Antonovics and Alexander 1989; Milgroom 2015; Peever and Milgroom 1994; Zhan and McDonald 2013). The presence of fungicides in the environment can act as a selective force driving the evolution of fungicide resistance if there is variation in the population with respect to fungicide sensitivity. Resistant isolates will leave more offspring relative to sensitive isolates in the presence of certain fungicides, increasing the frequency of resistant isolates in the population over time. However, if resistance carries a fitness cost, resistant individuals will be less competitive in the absence of the fungicide and the proportion of sensitive individuals in the population will increase (Ma and Michailides 2005).

Thiophanate-methyl is applied in Brazilian banana orchards to control yellow Sigatoka leaf spot. However, we hypothesize that C. musae populations are affected indirectly by thiophanatemethyl resulting in the evolution of fungicide resistance and the

Table 1. Disease severity (lesion diameter in $\mathrm{mm}$ ) on detached banana fruit treated with formulated thiophanate-methyl at label rate and inoculated with four sensitive and four moderately resistant isolates of Colletotrichum musae

\begin{tabular}{lcc}
\hline & \multicolumn{2}{c}{ Lesion diameter $(\mathbf{m m})^{\mathbf{z}}$} \\
\cline { 2 - 3 } Reaction phenotype & Without fungicide & With fungicide \\
\hline Sensitive & $16.53(3.07)$ & 0 \\
Moderately resistant & $18.73(2.83) \mathrm{a}$ & $15.81(3.41) \mathrm{b}$ \\
\hline
\end{tabular}

${ }^{\mathrm{z}}$ Values in each line (isolate class) followed by the same letter are not significantly different according to Student's $t$ test $(P=0.05)$. Values $( \pm)$ in parentheses represent standard errors. imminent breakdown in our ability to control postharvest banana anthracnose. The objectives of the present study were: i) characterize the sensitivity of $C$. musae isolates from Brazilian banana orchards to thiophanate-methyl in vitro, ii) evaluate the efficacy of thiophanate-methyl in controlling isolates with different levels of sensitivity, iii) identify mutations associated with resistance, and (iv) determine if there is a reduction in fitness associated with levels of thiophanate-methyl sensitivity.

\section{Materials and Methods}

Sampling and isolation. From 2012 to 2013, samples of the banana cultivars Ouro, Nanica, Nanicão, Caturra, Caru-roxa, D'água, Prata, Pacovan, Maçã, and Terra were collected from orchards located in the following Brazilian States: Alagoas, Bahia, Distrito Federal, Espírito Santo, Goiás, Minas Gerais, Para, Paraná, Pernambuco, Santa Catarina, and São Paulo. One unripe fruit was collected from a minimum of 10 plants in each orchard with each sampling point separated by at least 20 meters. Fruits were returned to the lab, washed in tap water, and kept in a humid chamber for 2 days at $25^{\circ} \mathrm{C}$ with continuous light. The fruit were then removed from the humid chamber and maintained in the lab for approximately 5 days and monitored for the appearance of lesions. Conidia from developing acervuli were transferred to Petri dishes containing potato dextrose agar (PDA) (Himedia, India) and incubated at $25^{\circ} \mathrm{C}$ with a $12 \mathrm{~h}$ photoperiod. According to the description of C. musae (Su et al. 2011; Weir et al. 2012), isolates with fast growing, white to gray, floccose, aerial mycelia and abundant orange conidial masses were cultured. Single conidium isolates were preserved on PDA slants at $4{ }^{\circ} \mathrm{C}$ and in cryogenic tubes containing autoclaved distilled water at room temperature.

The isolates morphologically identified as $C$. musae were tested with the $C$. musae species specific primers Musae_tub_33F and Musae_tub_387 (Vieira et al., unpublished data). These primers were designed based on unique polymorphisms in the $\beta$-tubulin gene sequences of $C$. musae. Genomic DNA was extracted following the CTAB (cetyl trimethyl ammonium bromide) protocol (Doyle and Doyle 1990) with slight modifications. PCR reactions were performed

Table 2. Partial nucleotide and amino acid sequences of the $\beta$-tubulin gene (TUB2) from thiophanate-methyl sensitive and moderately resistant isolates of Colletotrichum musae from Brazil

\begin{tabular}{|c|c|c|c|c|c|c|c|c|c|c|c|c|c|c|c|c|c|c|c|c|c|c|c|c|}
\hline $\begin{array}{l}\text { Isolates (GenBank } \\
\text { accession number) }\end{array}$ & & & & & & & & & Irtia & nuc & eotide & and & amir & 0 aci & seq & Ienc & & & & & & & & \\
\hline Sensitive & & & & & & & & & & & & & & & & & & & & & & & & \\
\hline $\begin{array}{r}\text { C. musae BA2 } \\
\text { (KX094293) }\end{array}$ & $\mathrm{C}$ & A & $\mathrm{G}$ & $\mathrm{C}$ & $\mathrm{T}$ & $\mathrm{G}$ & $\mathrm{G}$ & $\mathrm{T}$ & $\mathrm{C}$ & $\mathrm{G}$ & A & $\mathrm{G}$ & A & A & $\mathrm{C}$ & $\mathrm{T}$ & $\mathrm{C}$ & $\mathrm{C}$ & $\mathrm{G}$ & A & $\mathrm{C}$ & $\mathrm{G}$ & A & $\mathrm{G}$ \\
\hline $\begin{array}{l}\text { C. musae GM20 } \\
(\mathrm{KX} 094294)\end{array}$ & $\mathrm{C}$ & A & $\mathrm{G}$ & $\mathrm{C}$ & $\mathrm{T}$ & $\mathrm{G}$ & $\mathrm{G}$ & $\mathrm{T}$ & $\mathrm{C}$ & $\mathrm{G}$ & A & $\mathrm{G}$ & A & A & $\mathrm{C}$ & $\mathrm{T}$ & $\mathrm{C}$ & $\mathrm{C}$ & $\mathrm{G}$ & A & $\mathrm{C}$ & $\mathrm{G}$ & A & $\mathrm{G}$ \\
\hline $\begin{array}{l}\text { C. musae MM5 } \\
\text { (KX094295) }\end{array}$ & $\mathrm{C}$ & A & G & $\mathrm{C}$ & $\mathrm{T}$ & $\mathrm{G}$ & $\mathrm{G}$ & $\mathrm{T}$ & $\mathrm{C}$ & $\mathrm{G}$ & A & $\mathrm{G}$ & A & A & $\mathrm{C}$ & $\mathrm{T}$ & $\mathrm{C}$ & $\mathrm{C}$ & $\mathrm{G}$ & A & $\mathrm{C}$ & $\mathrm{G}$ & A & $\mathrm{G}$ \\
\hline $\begin{array}{l}\text { C. musae PN9 } \\
\text { (KX094292) }\end{array}$ & $\mathrm{C}$ & A & $\mathrm{G}$ & $\mathrm{C}$ & $\mathrm{T}$ & $\mathrm{G}$ & $\mathrm{G}$ & $\mathrm{T}$ & $\mathrm{C}$ & $\mathrm{G}$ & A & $\mathrm{G}$ & A & A & $\mathrm{C}$ & $\mathrm{T}$ & C & $\mathrm{C}$ & $\mathrm{G}$ & A & $\mathrm{C}$ & $\mathrm{G}$ & A & $\mathrm{G}$ \\
\hline $\begin{array}{l}\text { C. gloeosporioides } \\
\text { f. sp. aeschynomenes } \\
3.1 .3^{\mathrm{z}} \text { (U14138) }\end{array}$ & $\mathrm{C}$ & A & $\mathrm{G}$ & $\mathrm{C}$ & $\mathrm{T}$ & $\mathrm{G}$ & $\mathrm{G}$ & $\mathrm{T}$ & $\mathrm{C}$ & $\mathrm{G}$ & A & $\mathrm{G}$ & A & A & $\mathrm{C}$ & $\mathrm{T}$ & $\mathrm{C}$ & $\mathrm{C}$ & $\mathrm{G}$ & A & $\mathrm{C}$ & $\mathrm{G}$ & A & G \\
\hline Amino acid & & Q & & & $\mathrm{L}$ & & & V & & & $\mathrm{E}$ & & & $\mathrm{N}$ & & & $\mathrm{S}$ & & & $\mathrm{D}$ & & & $\mathrm{E}$ & \\
\hline Moderately resistant & & & & & & & & & & & & & & & & & & & & & & & & \\
\hline $\begin{array}{c}\text { C. musae RP3 } \\
\text { (KY711365) }\end{array}$ & $\mathrm{C}$ & A & G & $\mathrm{C}$ & $\mathrm{T}$ & G & G & $\mathrm{T}$ & $\mathrm{C}$ & G & A & G & A & A & $\mathrm{C}$ & $\mathrm{T}$ & $\mathrm{C}$ & $\mathrm{C}$ & G & A & $\mathrm{C}$ & G & A & G \\
\hline $\begin{array}{l}\text { C. musae RP4 } \\
\text { (KY711366) }\end{array}$ & $\mathrm{C}$ & $\mathrm{A}$ & G & $\mathrm{C}$ & $\mathrm{T}$ & G & G & $\mathrm{T}$ & $\mathrm{C}$ & G & A & G & $\mathrm{A}$ & $\mathrm{A}$ & $\mathrm{C}$ & $\mathrm{T}$ & $\mathrm{C}$ & $\mathrm{C}$ & G & A & $\mathrm{C}$ & G & A & G \\
\hline $\begin{array}{l}\text { C. musae RP5 } \\
\text { (KY711367) }\end{array}$ & $\mathrm{C}$ & A & G & $\mathrm{C}$ & $\mathrm{T}$ & G & G & $\mathrm{T}$ & $\mathrm{C}$ & G & A & G & A & A & $\mathrm{C}$ & $\mathrm{T}$ & $\mathrm{C}$ & $\mathrm{C}$ & G & A & $\mathrm{C}$ & G & A & G \\
\hline $\begin{array}{l}\text { C. musae RP6 } \\
\text { (KY711368) }\end{array}$ & $\mathrm{C}$ & A & G & $\mathrm{C}$ & $\mathrm{T}$ & G & G & $\mathrm{T}$ & $\mathrm{C}$ & G & A & G & A & A & $\mathrm{C}$ & $\mathrm{T}$ & $\mathrm{C}$ & $\mathrm{C}$ & G & A & $\mathrm{C}$ & G & $\mathrm{A}$ & G \\
\hline Amino acid & & $\mathrm{Q}$ & & & $\mathrm{L}$ & & & $\mathrm{V}$ & & & $\mathrm{E}$ & & & $\mathrm{N}$ & & & $\mathrm{S}$ & & & $\mathrm{D}$ & & & $\mathrm{E}$ & \\
\hline Codon position & & 191 & & & 192 & & & 193 & & & 194 & & & 195 & & & 196 & & & 197 & & & 199 & \\
\hline
\end{tabular}

y Codons with nucleotide substitutions and amino acid changes are highlighted in bold face.

${ }^{z}$ Partial sequence of the benomyl-sensitive isolate used as reference. 
using the following cycling parameters: initial denaturing for $3 \mathrm{~min}$ at $95^{\circ} \mathrm{C}$, followed by 30 cycles of $95^{\circ} \mathrm{C}$ for $30 \mathrm{~s}, 63^{\circ} \mathrm{C}$ for $30 \mathrm{~s}$, and $72^{\circ} \mathrm{C}$ for $30 \mathrm{~s}$. The amplification products were examined in a $1.5 \%$ agarose gel under ultraviolet light. C. musae isolates were identified by the presence of a single amplicon of approximately $350 \mathrm{bp}$. No amplification was expected for isolates of other Colletotrichum species.

In vitro thiophanate-methyl sensitivity assay. To quantify the sensitivity of C. musae isolates to thiophanate-methyl in vitro, isolates were screened by a mycelial growth assay using a commercial formulation of thiophanate-methyl (Cercobin $700 \mathrm{WP}, 700 \mathrm{~g} \mathrm{~kg}^{-1}$ active ingredient, Iharabras, São Paulo, SP, Brazil). Five-millimeter-diameter plugs were taken from the expanding margins of 7-day-old colonies grown on PDA, and transferred to the center of the PDA plates amended with the fungicide at the following active ingredient concentrations: 0 (control), 0.1, 0.2, 0.3, 0.3, 0.5, 1, 2, 3, 4, 10, 50, 100, and $500 \mu \mathrm{g} / \mathrm{ml}$. Each isolate was plated to three replicate plates at each fungicide concentration and incubated at $25^{\circ} \mathrm{C}$ in the dark. Two orthogonal measurements were taken from the colonies after 4 days of incubation. The percentage of mycelial growth inhibition compared with the control was calculated for all fungicide concentrations, and the concentration of the fungicide which inhibited fungal development by $50 \%\left(\mathrm{EC}_{50}\right)$ was determined for each individual isolate. The isolates were classified according to three different fungicide reaction phenotypes based on $\mathrm{EC}_{50}$ range: sensitive for $\mathrm{EC}_{50}$ below $10 \mu \mathrm{g} / \mathrm{ml}$; moderately resistant for $\mathrm{EC}_{50}$ between 10 and $100 \mu \mathrm{g} / \mathrm{ml}$; and highly resistant for $\mathrm{EC}_{50}$ above $100 \mu \mathrm{g} / \mathrm{ml}$. Representative isolates from each fungicide reaction phenotype were selected for subsequent assays.

In vivo thiophanate-methyl sensitivity assay. Thiophanate-methyl sensitivity was assessed in vivo by quantifying disease severity on banana fruits treated with the commercial formulation of thiophanatemethyl. The assay was carried out on banana fruit of the cultivar Pacovan at stage four of maturation (Ministério da Integração Nacional 2000) and not treated previously with any fungicide. Fruit were washed in tap water, surface disinfected in $1 \% \mathrm{NaOCl}$ for 3 min, then rinsed in sterile distilled water. Fruit surfaces were wounded at two points by pricking with a pin to a depth of $3 \mathrm{~mm}$. The commercial formulation of thiophanate-methyl was solubilized in sterile distilled water at the label rate (500 $\mu \mathrm{g}$ of active ingredient per milliliter). The wounded fruits were completely immersed in the fungicide solution for $10 \mathrm{~s}$ and kept at room temperature until completely dried.
Untreated fruit were immersed in distilled water. Treated and untreated fruit were inoculated with $40 \mu \mathrm{l}$ of a spore suspension $\left(1 \times 10^{6}\right.$ spores/ $\mathrm{ml}$ ) on the wounds, and kept in a humid chamber at $25^{\circ} \mathrm{C}$. The humid chamber was removed $24 \mathrm{~h}$ after inoculation and the fruit were maintained at the same temperature. Each replicate was represented by one fruit with two lesions, and three replicates per isolate were assayed. The disease severity was assessed by calculating the mean radial diameter of the lesions across all replicates. Differences in disease severity between treated and untreated fruits were determined for each fungicide reaction phenotype by a one-way analysis of variance (ANOVA) and means of each treatment were compared by the Student's $t$ test $(P=0.05)$ using the software Statistix v.10 (Analytical Software, Tallahassee, FL).

Analysis of thiophanate-methyl resistance using partial sequence of $\boldsymbol{\beta}$-tubulin gene. Partial sequences of the $\beta$-tubulin gene (TUB2) were analyzed to investigate the presence of genetic variability correlated with different levels of sensitivity to thiophanate-methyl. The PCR and sequence primers T1 and T22 (O’Donnell and Cigelnik 1997) and the internal sequencing primers Coll_Bt_Flint and Coll_Bt_Rlint (Rojas et al. 2010) were used to generate amplicons of approximately $1,330 \mathrm{bp}$ length. This set of primers was chosen to generate TUB2 sequences that contain several mutation points associated with different levels of benzimidazole resistance in Colletotrichum (Chung et al. 2006, 2010; $\mathrm{Hu}$ et al. 2015; Kongtragoul et al. 2011) and other plant pathogens (Albertini et al. 1999; Baraldi et al. 2003; Gafur et al. 1998; Koenraadt et al. 1992; Ma et al. 2003; Orbach et al. 1986; Yan and Dickman 1996; Yarden and Katan 1993). The PCR reactions were performed using the following parameters: initial denaturing for $5 \mathrm{~min}$ at $95^{\circ} \mathrm{C}$, followed by 35 cycles of $95^{\circ} \mathrm{C}$ for $30 \mathrm{~s}, 53^{\circ} \mathrm{C}$ for $30 \mathrm{~s}$, and $72^{\circ} \mathrm{C}$ for $1 \mathrm{~min}$ and $30 \mathrm{~s}$, followed by a final extension at $72^{\circ} \mathrm{C}$ for $10 \mathrm{~min}$. PCR products were purified and sequenced on an ABI 3730xl (Applied Biosystems) at Beckman Coulter Genomics (Danvers, MA).

Sequence reads were assembled into contigs and edited in Geneious 8.1 (Biomatters, New Zealand, Australia). A multiple sequence alignment of the $C$. musae sequences was estimated using the online implementation of MAFFT version 7 (Katoh and Toh 2013) using the G-INS-i iterative refinement method. The TUB2 sequence of a wild-type Colletotrichum isolate (GenBank accession number U14138) was included in the alignment. The isolate contains the complete CDS of TUB2 and was used as a reference for the assignment of codon positions and detection

Table 2. (continued from preceding page)

\begin{tabular}{|c|c|c|c|c|c|c|c|c|c|c|c|c|c|c|c|c|c|c|c|c|c|c|c|c|}
\hline $\begin{array}{l}\text { Isolates (GenBank } \\
\text { accession number) }\end{array}$ & & & & & & & & & rtial & nucl & eotide & and & amis & o aci & seq & ience & & & & & & & & \\
\hline Sensitive & & & & & & & & & & & & & & & & & & & & & & & & \\
\hline $\begin{array}{l}\text { C. musae BA2 } \\
\text { (KX094293) }\end{array}$ & A & $\mathrm{C}$ & $\mathrm{C}$ & $\mathbf{T}$ & $\mathbf{T}$ & $\mathbf{C}$ & $\mathrm{T}$ & $\mathrm{G}$ & $\mathrm{C}$ & A & $\mathrm{T}$ & $\mathrm{T}$ & $\mathrm{G}$ & A & $\mathrm{C}$ & A & A & $\mathrm{C}$ & $\mathrm{G}$ & A & $\mathrm{G}$ & $\mathrm{G}$ & $\mathrm{T}$ & $\mathrm{C}$ \\
\hline $\begin{array}{l}\text { C. musae GM20 } \\
\text { (KX094294) }\end{array}$ & A & $\mathrm{C}$ & $\mathrm{C}$ & $\mathbf{T}$ & $\mathbf{T}$ & $\mathbf{C}$ & $\mathrm{T}$ & $\mathrm{G}$ & $\mathrm{C}$ & A & $\mathrm{T}$ & $\mathrm{T}$ & $\mathrm{G}$ & A & $\mathrm{C}$ & A & A & $\mathrm{C}$ & $\mathrm{G}$ & A & $\mathrm{G}$ & $\mathrm{G}$ & $\mathrm{T}$ & $\mathrm{C}$ \\
\hline $\begin{array}{l}\text { C. musae MM5 } \\
\text { (KX094295) }\end{array}$ & A & $\mathrm{C}$ & $\mathrm{C}$ & $\mathbf{T}$ & $\mathbf{T}$ & $\mathbf{C}$ & $\mathrm{T}$ & $\mathrm{G}$ & $\mathrm{C}$ & A & $\mathrm{T}$ & $\mathrm{T}$ & $\mathrm{G}$ & A & $\mathrm{C}$ & A & A & $\mathrm{C}$ & $\mathrm{G}$ & A & $\mathrm{G}$ & $\mathrm{G}$ & $\mathrm{T}$ & $\mathrm{C}$ \\
\hline $\begin{array}{l}\text { C. musae PN9 } \\
\text { (KX094292) }\end{array}$ & $\mathrm{A}$ & $\mathrm{C}$ & $\mathrm{C}$ & $\mathbf{T}$ & $\mathbf{T}$ & $\mathbf{C}$ & $\mathrm{T}$ & $\mathrm{G}$ & $\mathrm{C}$ & A & $\mathrm{T}$ & $\mathrm{T}$ & $\mathrm{G}$ & A & $\mathrm{C}$ & A & A & $\mathrm{C}$ & $\mathrm{G}$ & A & $\mathrm{G}$ & $\mathrm{G}$ & $\mathrm{T}$ & $\mathrm{C}$ \\
\hline $\begin{array}{l}\text { C. gloeosporioides } \\
\text { f. sp. aeschynomenes } \\
3.1 .3^{z} \text { (U14138) }\end{array}$ & A & $\mathrm{C}$ & $\mathrm{C}$ & $\mathbf{T}$ & $\mathbf{T}$ & $\mathbf{C}$ & $\mathrm{T}$ & $\mathrm{G}$ & $\mathrm{C}$ & A & $\mathrm{T}$ & $\mathrm{T}$ & $\mathrm{G}$ & A & $\mathrm{C}$ & A & A & $\mathrm{C}$ & $\mathrm{G}$ & A & $\mathrm{G}$ & $\mathrm{G}$ & $\mathrm{T}$ & C \\
\hline Amino acid & & $\mathrm{T}$ & & & $\mathbf{Y}$ & & & $\mathrm{C}$ & & & I & & & $\mathrm{D}$ & & & $\mathrm{N}$ & & & $\mathrm{E}$ & & & A & \\
\hline Moderately resistant & & & & & & & & & & & & & & & & & & & & & & & & \\
\hline $\begin{array}{l}\text { C. musae RP3 } \\
\text { (KY711365) }\end{array}$ & A & $\mathrm{C}$ & $\mathrm{C}$ & $\mathbf{T}$ & $\mathbf{A}$ & $\mathbf{C}$ & $\mathrm{T}$ & G & $\mathrm{C}$ & A & $\mathrm{T}$ & $\mathrm{T}$ & G & A & $\mathrm{C}$ & A & A & $\mathrm{C}$ & G & A & G & $\mathrm{G}$ & $\mathrm{T}$ & $\mathrm{C}$ \\
\hline $\begin{array}{l}\text { C. musae RP4 } \\
\text { (KY711366) }\end{array}$ & A & $\mathrm{C}$ & $\mathrm{C}$ & $\mathbf{T}$ & $\mathbf{A}$ & $\mathbf{C}$ & $\mathrm{T}$ & G & $\mathrm{C}$ & A & $\mathrm{T}$ & $\mathrm{T}$ & G & A & $\mathrm{C}$ & A & A & $\mathrm{C}$ & G & A & G & G & $\mathrm{T}$ & $\mathrm{C}$ \\
\hline $\begin{array}{l}\text { C. musae RP5 } \\
\text { (KY711367) }\end{array}$ & A & $\mathrm{C}$ & $\mathrm{C}$ & $\mathbf{T}$ & $\mathbf{A}$ & $\mathbf{C}$ & $\mathrm{T}$ & G & $\mathrm{C}$ & A & $\mathrm{T}$ & $\mathrm{T}$ & G & A & $\mathrm{C}$ & $\mathrm{A}$ & A & $\mathrm{C}$ & G & A & G & G & $\mathrm{T}$ & $\mathrm{C}$ \\
\hline $\begin{array}{l}\text { C. musae RP6 } \\
\text { (KY711368) }\end{array}$ & A & $\mathrm{C}$ & $\mathrm{C}$ & $\mathbf{T}$ & $\mathbf{A}$ & $\mathbf{C}$ & $\mathrm{T}$ & G & $\mathrm{C}$ & A & $\mathrm{T}$ & $\mathrm{T}$ & G & A & $\mathrm{C}$ & A & A & $\mathrm{C}$ & G & A & G & G & $\mathrm{T}$ & $\mathrm{C}$ \\
\hline Amino acid & & $\mathrm{T}$ & & & $\mathbf{F}$ & & & $\mathrm{C}$ & & & I & & & $\mathrm{D}$ & & & $\mathrm{N}$ & & & $\mathrm{E}$ & & & $\mathrm{A}$ & \\
\hline Codon position & & 200 & & & 201 & & & 202 & & & 203 & & & 204 & & & 205 & & & 206 & & & 206 & \\
\hline
\end{tabular}


of point mutations. The polymorphic sites in the alignment were identified using the software MEGA 6.06 (Pennsylvania State University, PA). Sequences generated in the present study were deposited to GenBank.

Analysis of fitness components. The following fitness components were determined for the $C$. musae isolates with different levels of resistance to thiophanate-methyl: mycelial growth rate, spore production in vitro, spore germination, osmotic sensitivity, and virulence. For all assays, isolates were transferred to PDA plates (five plates per isolate) and incubated for 7 days at $25^{\circ} \mathrm{C}$ with continuous fluorescent light to enhance sporulation. All fitness assays were conducted with three replicates per isolate.

Mycelial growth rate. Five-millimeter-diameter plugs were taken from the edge of 7-day-old colonies and transferred to the center of the PDA plates. Each isolate was plated to three replicate plates and incubated as described above. Four radial measurements were taken from the edge of the plug to the margin of the colony after 4 days of incubation, resulting in four radial measurements per replicate that were used to calculate the mycelial growth rate $(\mathrm{mm} / \mathrm{day})$.

Spore production. Colonies with active sporulation were rinsed with $20 \mathrm{ml}$ of distilled water and the conidial suspension was filtered through double-layered cheesecloth. The spore concentration in the suspension was measured with the aid of a hemocytometer and expressed as number of spores per milliliter of suspension. Four droplets were counted for each plate and represented one replicate. The concentration of the solutions were adjusted after measuring to $1 \times 10^{6}$ spores $/ \mathrm{ml}$ to be used in the spore germination assay.

Spore germination. Fifty microliters of conidial suspension were transferred to four equidistant points on Petri plates containing $2 \%$ water agar. Each drop was covered with a coverslip and plates were incubated for $12 \mathrm{~h}$ at $25^{\circ} \mathrm{C}$ in the dark. One hundred conidia were examined under each with a compound microscope (Olympus BX41, Tokyo, Japan) to determine the germination percentage. A conidium was considered germinated if the germ tube was at least half the length of the spore.

Osmotic sensitivity. Five-millimeter-diameter plugs were taken from the expanding margins of 7-day-old colonies grown on PDA, and transferred to the center of PDA plates amended with 0 (control), 1 , 2, 4, 6, and $8 \%(\mathrm{w} / \mathrm{v}) \mathrm{NaCl}$. Each isolate was plated to three replicates plates at each $\mathrm{NaCl}$ concentration and incubated at $25^{\circ} \mathrm{C}$ in the dark. Two orthogonal measurements were taken from the colonies after 4 days of incubation. The percentage of mycelial growth inhibition compared with the control was calculated for all $\mathrm{NaCl}$ concentrations. The concentration of the $\mathrm{NaCl}$ that inhibited fungal development by $50 \%\left(\mathrm{EC}_{50} \mathrm{~N}\right)$ was determined for each individual isolate.

Virulence. Disease severity on untreated fruits for each isolate from the in vivo thiophanate-methyl sensitivity assay were used as a proxy for virulence. Untreated fruits inoculated with $40 \mu \mathrm{l}$ of sterile distilled water were used as negative control.

Data analysis. ANOVA were performed individually for each fitness component. Differences among different fungicide reaction phenotypes were determined by ANOVA and means were compared by the Student's $t$ test $(P=0.05)$ using the software Statistix v.10 (Analytical Software, Tallahassee, FL). The normality of residuals were tested using the Levene's test, and data were transformed to if the assumption of normality was rejected.

\section{Results}

Sampling and isolation. A total of 139 Colletotrichum isolates similar in morphology to $C$. musae were obtained from the sampled orchards in Brazil. In the PCR test with the C. musae species-specific primers, all isolates produced a single amplicon of approximately $350 \mathrm{bp}$, which confirms the assignment of these isolates to the species C. musae.

In vitro thiophanate-methyl sensitivity assay. $\mathrm{EC}_{50}$ values varied from 0.003 to $48.73 \mu \mathrm{g} / \mathrm{ml}$. Out of 139 isolates, 133 (96\%) were classified as sensitive to thiophanate-methyl based on $\mathrm{EC}_{50}$ values ranging from 0.003 to $4.84 \mu \mathrm{g} / \mathrm{ml}$ (Fig. 1). The remaining six isolates (4\%) presented $\mathrm{EC}_{50}$ values ranged from 10.43 to $48.73 \mu \mathrm{g} / \mathrm{ml}$ and were classified as moderately resistant. Four sensitive and four moderately resistant isolates were randomly selected for the subsequent assays. Resistant and highly resistant isolates were not found.

In vivo thiophanate-methyl sensitivity assay. Banana fruit inoculated with sensitive isolates developed typical anthracnose symptoms, while no symptoms were observed on fruits treated with thiophanate-methyl (Fig. 2). The moderately resistant isolates caused anthracnose symptoms on both treated and untreated banana fruit. However, the disease severity significantly decreases in the treated fruit compared with the untreated fruit $(P=0.025)$ (Table 1).

Analysis of thiophanate-methyl resistance using partial sequence of $\boldsymbol{\beta}$-tubulin gene. Non-synonymous mutations in the TUB2 sequences of $C$. musae isolates were correlated with variation in thiophanate-methyl resistance (Table 2). Sensitive isolates were identical in sequence in the coding region of TUB2 to the wild-type Colletotrichum sequence. In contrast, moderately resistant isolates presented a transversion from thymine (T) to adenine (A) at nucleotide position 978. This point mutation in the second position of codon 200 results in an amino acid change from a phenylalanine (TTC) in the wild-type and sensitive isolates to a tyrosine (TAC) in the moderately resistant isolates.

Analysis of fitness components. No statistical difference was observed between the thiophanate-methyl sensitive and resistant isolates for mycelial growth rate $(P=0.098)$, spore production $(P=0.066)$, spore germination $(P=0.366)$, osmotic sensitivity $(P=0.051)$, and virulence on banana fruit $(P=0.057)$ (Table 3$)$.

\section{Discussion}

This is the first report of sensitivity of $C$. musae from banana orchards to thiophanate-methyl and its influence on fitness components in sensitive and resistant isolates. Previous studies have reported resistance to other MBC fungicides in C. musae populations from other countries (de Lapeyre de Bellaire and Dubois 1997; Griffee 1973; Hostachy et al. 1990; Johanson and Blasquez 1992; Quimio 1976; Slabaugh and Grove 1982).

The six isolates that were moderately resistant to thiophanatemethyl were from a single orchard in Registro, São Paulo. While most of the sampled area, whose production is primarily aimed at domestic markets, has not adopted a regular schedule of fungicide applications due to the low cost-benefit, banana production in Registro is carried out under high levels of technology. This includes the regular use of fungicides, including thiophanate-methyl, for the management of yellow Sigatoka leaf spot on the highly susceptible banana cultivar Prata. Fungicides that are registered for the control of Sigatoka in Brazil (MAPA 2016) are applied following a regular schedule regardless of disease pressure. While the fungicide applications are aimed at controlling yellow Sigatoka leaf spot, our results indicate the use of thiophanate-methyl to control yellow Sigatoka leaf spot is leading to directional selection of moderately resistant isolates in the C. musae population from the Registro orchard.

Table 3. Comparison of mycelial growth rate (MGR), spore production (SP), spore germination (SG), osmotic sensitivity (EC $\left.{ }_{50} \mathrm{~N}\right)$, and virulence (lesion diameter) on banana fruits (VIR) between thiophanate-methyl sensitive and moderately resistant isolates of Colletotrichum musae ${ }^{\mathrm{z}}$

\begin{tabular}{lccccc}
\hline Reaction phenotype & MGR $(\mathbf{m m} / \mathbf{d a y})$ & $\mathbf{S P}\left(\times \mathbf{1 0}^{\mathbf{6}} \mathbf{s p o r e} / \mathbf{m l}\right)$ & $\mathbf{S G}(\boldsymbol{\%})$ & $\mathbf{E C}_{\mathbf{5 0}} \mathbf{N}(\boldsymbol{\%} \mathbf{N a C l})$ & VIR $(\mathbf{m m})$ \\
\hline Sensitive & $19.31(0.52)$ & $4.62(1.25)$ & $63.42(14.5)$ & $3.89(0.17)$ & $16.53(3.07)$ \\
Moderately resistant & $16.96(2.17)$ & $2.25(1.89)$ & $70.58(7.88)$ & $3.03(0.68)$ & $18.73(2.83)$ \\
$P$-value & 0.0982 & 0.0663 & 0.366 & 0.0517 & 0.0570 \\
\hline
\end{tabular}

${ }^{\mathrm{z}}$ Reaction phenotypes values for each variable do not differ significantly according to Student's $t$ test $(P=0.05)$. Values $( \pm)$ in parentheses represent standard errors. 
Fungicide resistance is uncommon in populations that have not been subjected to fungicide application because alleles associated with resistance are rare or absent. However, these alleles increase in frequency in the presence of fungicides depending on the frequency and strength of selection (Brent and Hollomon 2007a, b). Factors such as increasing the efficacy of the fungicide, increasing the frequency of fungicide applications, and a greater difference in sensitivity between resistant and sensitive individuals in the field can lead to greater selective pressure (Bergamin Filho and Amorim 2001). We observed a significant difference in fungicide sensitivity between sensitive and moderately resistant isolates in vitro. Sensitive isolates were inhibited by concentrations above $0.5 \mu \mathrm{g} / \mathrm{ml}$, while moderately resistant isolates kept growing when exposed to concentrations up to $500 \mu \mathrm{g} / \mathrm{ml}$ (data not shown). The need for high concentrations of thiophanate-methyl to inhibit the growth of moderately resistant isolates, combined with high frequency applications of the fungicide, may lead the moderately resistant isolates to become dominant in the $C$. musae population in the Registro orchard.

Our in vivo results reveal the low efficacy of thiophanate-methyl in controlling moderately resistant isolates of $C$. musae on fruit. While thiophanate-methyl efficiently controlled banana anthracnose when inoculated with sensitive isolates, only a minor reduction in disease severity was achieved when the fruits were inoculated with resistant isolates. This result may have practical implications for controlling anthracnose in the postharvest period. Banana fruit produced in the Registro orchard are destined for other countries and are treated with carbendazim to avoid the development of anthracnose symptoms during transportation and marketing. However, since carbendazim is also an MBC fungicide, this treatment may be not efficacious and symptomatic fruit may be rejected at international borders. This obstacle to production for international markets is starting to be reported for some producers in this region.

A single-base-pair mutation converting codon 200 from phenylalanine to tyrosine in the coding region of TUB2 is correlated with thiophanate-methyl resistance in the $C$. musae isolates we evaluated. The same correlation has been reported for $C$. gloeosporioides (Chung et al. 2006, 2010) and other plant pathogenic fungi (Albertini et al. 1999; Koenraadt et al. 1992; Yarden and Katan 1993). Although different point mutations have been correlated with levels of benzimidazole resistance in fungal isolates (Albertini et al. 1999; Baraldi et al. 2003; Gafur et al. 1998; Koenraadt et al. 1992; Ma et al. 2003; Orbach et al. 1986; Yan and Dickman 1996; Yarden and Katan 1993), no other mutations were observed in TUB2 sequences among the moderately resistant C. musae isolates.

Information about fitness components of resistant and sensitive fungi to fungicides is useful to determine disease management

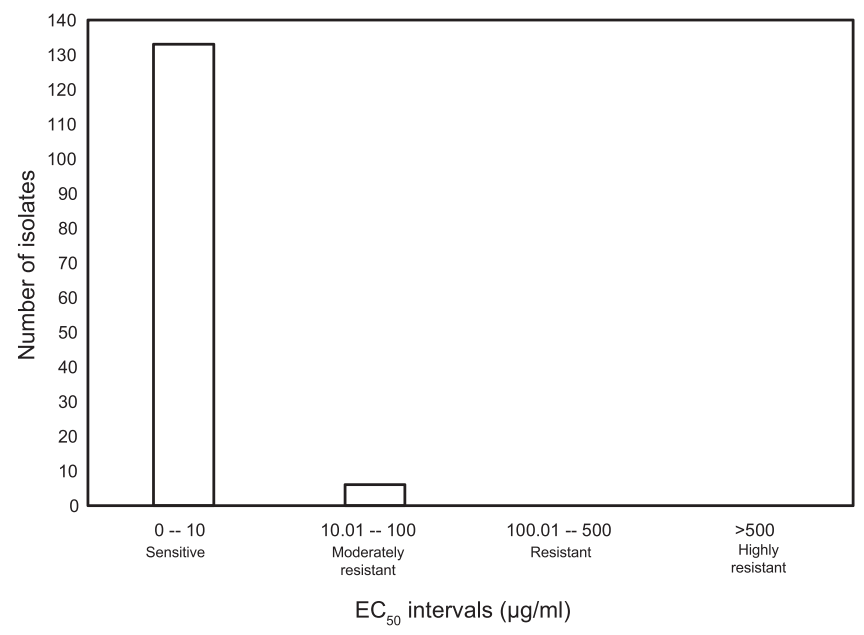

Fig. 1. Frequency distributions of effective thiophanate-methyl concentrations to inhibit $50 \%$ of the mycelial growth $\left(\mathrm{EC}_{50}\right)$ for 139 Colletotrichum musae isolates collected from Brazilian banana orchards. strategies and prevent the development of resistance (Antonovics and $\mathrm{Al}-$ exander 1989; Ma and Michailides 2005). Fungicide resistance is a genetically inherited trait that may impose a fitness penalty, which can negatively affect fungal growth, reproduction, or pathogenicity (Brent and Hollomon 2007b). Fitness components such as growth rate and virulence may reflect the pathogenic potential of the isolates in the field. On other hand, spore production and spore germination may reflect the potential of the isolates to reproduce, spread, and establish new infections. Our results indicate the evolution of thiophanate-methyl resistance has no impact on fitness and both sensitive and moderately resistant isolates are equally likely to be capable of surviving and persisting in banana orchards. This suggests moderately resistant isolates of $C$. musae may persist in banana orchards even without the selection pressure from multiple applications of thiophanate-methyl.

A
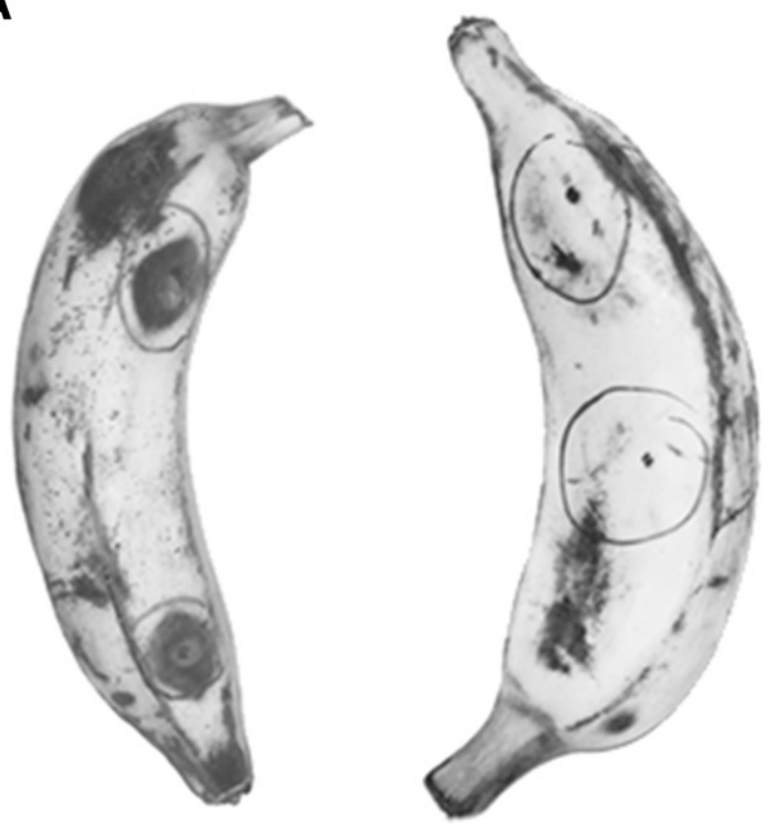

C

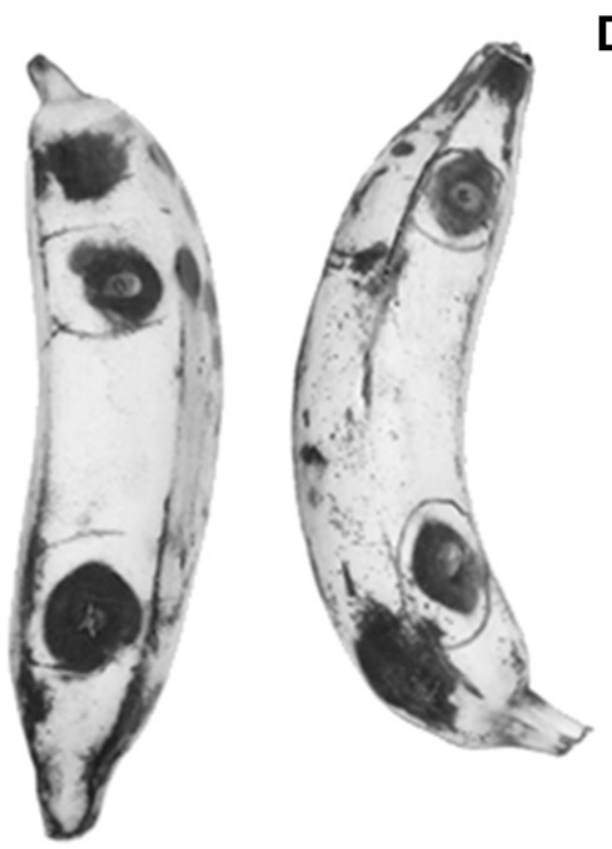

Fig. 2. Efficacy of thiophanate-methyl in controlling sensitive (A, B) and moderately resistant (C, D) isolates of Colletotrichum musae on banana fruits. A and C represent fruits untreated with thiophanate-methyl. 
The occurrence of $C$. musae isolates with moderate resistance to thiophanate-methyl in one of the most important regions of banana production in Brazil is a reality. Although fungicide resistance management can attenuate the emergence of nonsensitive isolates in field populations (Brent and Hollomon 2007a), there are no studies on the most appropriate strategies for the management of fungicide resistance in banana orchards. Since sensitive and moderately resistant isolates have the same adaptive potential, the first management strategy to be adopted is the use of other fungicides with different modes of action from benzimidazoles. Additional strategies for the use of chemical control include the application of a mixture of fungicides with distinct modes of action and applications only when strictly necessary following the dose recommended by manufacturers. Other disease management practices include removal of crop residues from the field, preventing injuries on the fruit surface during harvest, and the postharvest chemical treatment of fruit.

\section{Acknowledgments}

This study was funded by "Fundação de Amparo a Ciência e Tecnologia de Pernambuco - FACEPE" (process number APQ-0790-5.01/12), the "Conselho Nacional de Desenvolvimento Científico e Tecnológico - CNPq" (universal number 442279/2014-0), and the Louisiana State University Agricultural Center. Willie A. S. Vieira acknowledges "Ciência sem Fronteiras - CNPq" (process number 99999.006035/2014-00), FACEPE (process number IBPG-0855-5.01/11), and the Department of Plant Pathology and Crop Physiology (Louisiana State University AgCenter, Baton Rouge, Louisiana, U.S.A.) for financial support and the opportunity for student exchange. Marcos P. S. Câmara and Sami J. Michereff acknowledge CNPq for the research fellowship.

\section{Literature Cited}

Albertini, C., Gredt, M., and Leroux, P. 1999. Mutations of the b-Tubulin gene associated with different phenotypes of benzimidazole resistance in the cereal eyespot fungi Tapesia yallundae and Tapesia acuformis. Pestic. Biochem. Physiol. 64:17-31.

Antonovics, J., and Alexander, H. M. 1989. The concept of fitness in plant fungal pathogen systems. Pages 185-214 in: Plant Disease Epidemiology. K. J. Leonard and W. E. Fry, eds. McGraw-Hill, New York.

Avenot, H. F., and Michailides, T. J. 2010. Progress in understanding molecular mechanisms and evolution of resistance to succinate dehydrogenase inhibiting (SDHI) fungicides in phytopathogenic fungi. Crop Prot. 29:643-651.

Baraldi, E., Mari, M., Chierici, E., Pondrelli, M., Bertolini, P., and Pratella, G. C. 2003. Studies on thiabendazole resistance of Penicillium expansum of pears: Pathogenic fitness and genetic characterization. Plant Pathol. 52:362-370.

Bergamin Filho, A., and Amorim, L. 2001. Comparative epidemiology between temperate and tropical pathosystems: its consequences for fungicide resistance. Fitopatol. Bras. 26:119-127.

Brent, K. J., and Hollomon, D. W. 2007a. Fungicide resistance in crop pathogens: How can it be managed? Fungicide Resistance Action Committee, Brussels.

Brent, K. J., and Hollomon, D. W. 2007b. Fungicide resistance: The assessment of risk. Fungicide Resistance Action Committee, Brussels.

Chung, W.-H., Chung, W.-C., Peng, M.-T., Yang, H.-R., and Huang, J.-W. 2010. Specific detection of benzimidazole resistance in Colletotrichum gloeosporioides from fruit crops by PCR-RFLP. N. Biotechnol. 27:17-24.

Chung, W.-H., Ishii, H., Nishimura, K., Fukaya, M., Yano, K., and Kajitani, Y. 2006. Fungicide sensitivity and phylogenetic relationship of anthracnose fungi isolated from various fruit crops in Japan. Plant Dis. 90:506-512.

Cordeiro, Z. J. M. 1997. Doenças e nematóides. Pages 69-86 in: Banana para exportação: aspectos técnicos da produção, 2nd ed. E. J. Alves et al., eds. EMBRAPA-SPI, Brasília, Brazil

Davidse, L. C. 1986. Benzimidazole fungicides: Mechanism of action and biological impact. Annu. Rev. Phytopathol. 24:43-65.

de Lapeyre de Bellaire, L., and Dubois, C. 1997. Distribution of thiabendazoleresistant Colletotrichum musae isolates from Guadeloupe banana plantations. Plant Dis. 81:1378-1383.

Doyle, J. J., and Doyle, J. L. 1990. Isolation of plant DNA from fresh tissue. Focus $12: 13-15$.

Eckert, J. W., and Ogawa, J. M. 1985. The chemical control of postharvest diseases: subtropical e tropical fruits. Annu. Rev. Phytopathol. 23:421-454.

FAO. 2014. FAOSTAT, Food and Agricultural Organization of the United Nations. Available at: http://www.fao.org/faostat/en/. Accessed 13 February 2016.

Gafur, A., Tanaka, C., Shimizu, K., Ouchi, S., and Tsuda, M. 1998. Molecular analysis and characterization of the Cochliobolus heterostrophus $\beta$-tubulin gene and its possible role in conferring resistance to benomyl. J. Gen. Appl. Microbiol. 44:217-223.

Griffee, P. J. 1973. Resistance to benomyl and related fungicides in Colletotrichum musae. Trans. Br. Mycol. Soc. 60:433-439.

Hostachy, B., Vegh, I., Leroux, P., Jacquemot, E., Foucher, S., and Pigou, R. 1990. Bananes de la Martinique. Incidence des problèmes fongiques sur la qualité. Phytoma 420:37-44.
Hu, M.-J., Grabke, A., Dowling, M. E., Holstein, H. J., and Schnabel, G. 2015 Resistance in Colletotrichum siamense from peach and blueberry to thiophanatemethyl and azoxystrobin. Plant Dis. 99:806-814.

Johanson, A., and Blasquez, B. 1992. Fungi associated with banana crown-rot on field-packed fruit from the Windward Islands and assessment of their sensitivity to the fungicides thiabendazole, prochloraz, and imazalil. Crop Prot. 11:79-83.

Katoh, K., and Toh, H. 2013. MAFFT multiple sequence alignment software version 7: improvements in performance and usability. Mol. Biol. Evol. 30: $772-780$

Koenraadt, H., Somerville, S. C., and Jones, A. L. 1992. Characterization of mutations in the beta-tubulin gene of benomyl-resistant field strains of Venturia inaequalis and other plant pathogenic fungi. Phytopathology 82 1348-1354

Kongtragoul, P., Nalumpang, S., Miyamoto, Y., Izumi, Y., and Akimitsu, K. 2011. Mutation at codon 198 of tub2 gene for carbendazim resistance in Colletotrichum gloeosporioides causing mango anthracnose in Thailand. J. Plant Prot. Res. 51: 377-384

Kuck, K. H., Leadbeater, A., and Gisi, U. 2012. FRAC mode of action classification and resistance risk of fungicides. Pages 539-557 in: Modern crop protection compounds, 2nd Ed. W. Krämer, U. Schirmer, P. Jeschke, and M. Witschel, eds. Wiley-VCH Verlag, Weinheim, Germany.

Lim, J., Lim, T. H., and Cha, B. 2002. Isolation and identification of Colletotrichum musae from imported bananas. Plant Pathol. J. 18:161-164.

Lin, T., Xu, X. F., Dai, D. J., Shi, H. J., Wang, H. D., and Zhang, C. Q. 2016 Differentiation in development of benzimidazole resistance in Colletotrichum gloeosporioides complex populations from strawberry and grape hosts. Australas. Plant Pathol. 45:241-249.

Ma, Z., Felts, D., and Michailides, T. J. 2003. Resistance to azoxystrobin in Alternaria isolates from pistachio in California. Pestic. Biochem. Physiol. 77:66-74.

Ma, Z., and Michailides, T. J. 2005. Advances in understanding molecular mechanisms of fungicide resistance and molecular detection of resistant genotypes in phytopathogenic fungi. Crop Prot. 24:853-863.

MAPA. 2016. Agrofit - Sistema de agrotóxicos fitossanitários. Resource database. http://extranet.agricultura.gov.br/agrofit_cons/principal_agrofit_cons. Accessed 13 February 2016.

Maymon, M., Zveibil, A., Pivonia, S., Minz, D., and Freeman, S. 2006. Identification and characterization of benomyl-resistant and -sensitive populations of Colletotrichum gloeosporioides from Statice (Limonium spp.). Phytopathology 96:542-548.

Meredith, D. S. 1960. Studies on Gloeosporium musarum Cke. \& Mass. causing storage rots of Jamaican banana. I. Anthracnose and its chemical control. Ann. Appl. Biol. 48:279-290.

Milgroom, M. G. 2015. Population Biology of Plant Pathogens: Genetics, Ecology, and Evolution. APS Press, St. Paul, MN

Ministério da Integração Nacional. 2000. Frutiséries. Resource document. http:// www.mi.gov.br/web/guest/infraestrutura-hidrica/publicacoes. Accessed on 10 February 2016.

O’Donnell, K., and Cigelnik, E. 1997. Two divergent intragenomic rDNA ITS 2 types within a monophyletic lineage of the fungus Fusarium are nonorthologous. Mol. Phylogenet. Evol. 7:103-116.

Orbach, J. M., Porro, E. B., and Yanofsky, C. 1986. Cloning and characterization of the gene for $\beta$-tubulin from a benomyl-resistant mutant of Neurospora crassa and its use as a dominant selectable marker. Mol. Cell. Biol. 6:2452-2461.

Peever, T. L., and Milgroom, M. G. 1994. Lack of correlation between fitness and resistance to sterol biosynthesis-inhibiting fungicides in Pyrenophora teres. Phytopathology 84:515-519.

Peres, N. A. R. 1998. Caracterização patogênica, morfológica, cultural e molecular de Colletotrichum acutatum e Colletotrichum spp. em frutas pós-colheita M.Sc. thesis. Faculdade de Ciências Agronômicas da Universidade Estadual de São Paulo, Botucatu, Brazil.

Peres, N. A. R., Souza, N. L., Peever, T. L., and Timmer, L. W. 2004. Benomyl sensitivity of isolates of Colletotrichum acutatum and C. gloeosporioides from Citrus. Plant Dis. 88:125-130.

Prusky, D., and Plumbley, R. A. 1992. Quiescent infections of Colletotrichum in tropical and subtropical fruits. Pages 289-307 in: Colletotrichum: Biology, Pathology and Control. J. A. Bailey and M. J. Jeger, eds. CABI, Wallingford, U.K.

Quimio, T. H. 1976. Variability in Colletotrichum musae (Berk. et Curt.) V. Arx and its significance in chemical control. Phillip. Phytopathol. 12:40-50.

Ramdial, H., Hosein, F. N., and Rampersad, S. N. 2016. Plant Dis. 100:1146-1152.

Rojas, E. I., Rehner, S. A., Samuels, G. J., Van Bael, S. A., Herre, E. A., Cannon, P., Chen, R., Pang, J. F., Wang, R. W., Zhang, Y. P., Peng, Y.-Q., and Sha, T. 2010. Colletotrichum gloeosporioides s.l. associated with Theobroma cacao and other plants in Panamá: multilocus phylogenies distinguish host-associated pathogens from asymptomatic endophytes. Mycologia 102:1318-1338.

Sepiah, M., Acedo, A. L., Sabari, S. D., Ilag, L. L., and Kuthubutheen, A. J. 1990. Post harvest physiology of banana. Pages 104-111 in: Banana Fruit Development - Post Harvest Physiology, Handling and Marketing in ASEAN. A. Hassan and E. B. Pantatico, eds. ASEAN Food, Handling Bureau, Malaysia.

Simmonds, T. H., and Mitchell, R. S. 1940. Black end and anthracnose of the banana with special reference to Gloeosporium musarum Cke. \& Mass. Bull. Counc. Sci. Ind. Res. 131:6-63. 
Slabaugh, W. R., and Grove, M. D. 1982. Postharvest diseases of bananas and their control. Plant Dis. 66:746-750.

Su, Y. Y., Noireung, P., Liu, F., Hyde, K. D., Moslem, M. A., Bahkali, A. H., AbdElsalam, K. A., and Cai, L. 2011. Epitypification of Colletotrichum musae, the causative agent of banana anthracnose. Mycoscience 52:376-382.

Weir, B. S., Johnston, P. R., and Damm, U. 2012. The Colletotrichum gloeosporioides species complex. Stud. Mycol. 73:115-180.

Wong, F. P., de la Cerda, K. A., Hernandez-Martinez, R., and Midland, S. L. 2008. Detection and characterization of benzimidazole resistance in California populations of Colletotrichum cereale. Plant Dis. 92: 239-246.
Yan, K., and Dickman, M. B. 1996. Isolation of a $\beta$-tubulin gene from Fusarium moniliforme that confers cold-sensitive benomyl resistance. Appl. Environ. Microbiol. 62:3053-3056.

Yarden, O., and Katan, T. 1993. Mutations leading to substitutions at amino acids 198 and 200 of $\beta$-tubulin that correlates with benomyl-resistance phenotypes of field isolates of Botrytis cinerea. Phytopathology 83:1478-1483.

Zambolim, L., do Vale, F. X. R., Monteiro, A. J. A., and Costa, H. 2002. Controle de doenças de plantas - fruteiras. Vol. 2. Suprema Gráfica e Editora, Visconde do Rio Branco, Brazil.

Zhan, J., and McDonald, B. A. 2013. Experimental measures of pathogen competition and relative fitness. Annu. Rev. Phytopathol. 51:131-153. 